Ssciendo Studia Anglica Posnaniensia 56 (2021): 121-147

doi: 10.2478/stap-2021-0019

\title{
LEXICAL BORROWING IN THE LIGHT OF DIGITAL RESOURCES: NYET AS A CASE STUDY
}

\author{
MirosŁaWA PODHAJECKA ${ }^{1}$
}

\begin{abstract}
The mere appearance of a foreign word does not necessarily mark the birth of a loanword, which requires documented usage by the speech community. Relatively little research has been dedicated so far to the "prenatal" stage that would investigate the tentative infiltration of foreign-derived words. Nyet, a borrowing from Russian, is taken as a case in point. Although its first recorded instance in the Oxford English Dictionary (OED3) is dated to 1928, it had been increasingly recognized in English for several decades. This article focuses on textual attestations for nyet discovered in a range of digital resources, including British and American newspaper archives, and discusses their usefulness as potential antedatings for OED3's entry.
\end{abstract}

Keywords: OED3; nyet; loanword; Russian; citation; antedating; British English; American English; digital resources.

\section{Introduction}

This paper seeks to verify historical facts concerning nyet on the basis of an extensive collection of English digital materials. It aims to investigate how the form morphed from a native Russian word into a borrowing, and to what extent British English (BrE) and American English (AmE) uses contributed to its growing recognition. My approach is based on the premise, crude and simplistic though it may be, that texts published in Great Britain reflect $\mathrm{BrE}$ and those published in the United States reflect AmE. The boundary between the two varieties of English has thus been drawn without taking into consideration any structural or lexical characteristics.

1 Institute of Linguistics, University of Opole; Pl. Kopernika 11, 45-040 Opole. mpodhajecka@uni.opole.pl 
The digital resources to which reference has been made include a number of attestations for both senses of nyet, as defined in the third edition of the Oxford English Dictionary (henceforth, OED3), which provide ample illustration of the word's development in English. Importantly, some of the attestations predate the citations recorded in OED3. The aim of the paper is to ascertain, firstly, how intensely nyet penetrated English before it was officially acknowledged as a loanword; secondly, whether the collected evidence is likely to update OED3 and if so, on what grounds; and, thirdly, to what extent we may map the exact route of transmission.

Morton Benson, the first researcher to analyze Russianisms in the American press, argued that "repeated use alone does not necessarily lead to acceptance by dictionaries. For example, the Russian words $d a$ 'yes' and nyet 'no' have been used in American newspapers for years, and understood by many Americans, and yet are not found in dictionaries of English" (Benson 1962: 46). In the same vein, Derbyshire (1971: 41) noted in his study that "words of the type nyet (the Russian negative reply нет 'nо') are considered to be foreignisms [...] and are thereby omitted". This stance may have been valid half a century ago, but it can no longer be justified today. Since foreignisms and loanwords are "impossible to distinguish consistently and reliably in all instances", as Durkin (2014: 18-19) writes, frequency of use has become the key parameter in present-day historical lexicography. Unsurprisingly, OED3 treats nyet as an eligible headword, ${ }^{2}$ tracing it back to 1928 and its lexical antecedent to 1891 .

2 According to one of the reviewers, nyet is much closer to a foreignism than to a fully-fledged loanword on what has been termed "the borrowing scale" (cf. Thomason \& Kaufman 1992: 74-76), the more so because many headwords in OED3 represent the former rather than the latter. This seems a fair criticism, but two aspects are worth highlighting. Firstly, there is a significant difference between the way headwords were treated in OED1/OED2 and the way they are handled in OED3. In the past, it was sufficient for a word (e.g., burka, gopak, and shashlik) to be recorded merely five times in printed sources. To deserve inclusion in OED3, by contrast, a lexical item needs to be documented in thousands of sources. The threshold for citations from Google Books would come somewhere between these two extremes (Durkin, p.c., December 2008). In this way, the OED wordlist exhibits both the old and the new approach (on which see Brewer 2013: 101-126), including words that have achieved broad currency, but also a large number of rare ones (Durkin 2014: 424). Secondly, establishing the status of a borrowing unambiguously is often impossible. This is why the distinction between Fremdwörter (foreignisms) and Lehnwörter (loanwords) has been dropped altogether in OED3 in favor of more detailed information on spelling, morphology, pronunciation, and etymology (Tulloch 2002: 240). The two terms are likely to be operative, but the dimension along which they differ is by no means "identical to the degree of adaptation" (Haspelmath 2009: 43, cf. Fischer 2010: 9; de Barros 2018: 64-65). It is difficult to determine, moreover, when exactly a word becomes a member of the recipient language's lexicon because it may be applied by one group of speakers, but not necessarily by another. In what follows, foreignism is used in the meaning 'a word of foreign origin' and loanword denotes 'a foreign word taken into the recipient language whatever its degree of integration'. 


\section{Lexical borrowing}

Lexical borrowing, or taking over individual words from one language into another, is a common outcome of contact-induced change (e.g., Hock 1991: 380; Thomason 2001: 10; Haspelmath 2009; Treffers-Daller 2010: 25; Grant 2015: 431). Foreign words introduced by bilingual speakers as innovations may subsequently be reproduced by "adopters, who are centrally placed in the society and are open to new developments" (Myers-Scotton 2006: 212). At the hands of monolingual speakers, as Weinreich (1970: 44) puts it, they are adapted to the phonology, orthography, morphology, and syntax of the recipient language. The results of the process are responsible for more or less striking differences between the foreign model and the native replica, particularly when it comes to sound and spelling (e.g., Winford 2010: 174-175).

Lexical borrowing can be difficult to distinguish from other types of contact phenomena such as lexical transfer, when a group of speakers shifts from one language to another, and code-switching, when elements of two or more languages are mixed within the same utterance (e.g., Durkin 2009: 286; TreffersDaller 2010: 17; MacSwan 2012: 323). This problem is especially pertinent in the context of mixed-language historical texts, which reflect "different levels of language contact" (McDonald 2015: 54) and, consequently, varying patterns of bilingual or multilingual language use. Schendl (cited in Durkin 2014: 295) suggests that such texts cover a continuum of uses ranging from code-switching to established borrowings (see also Schendl 2002; Myers-Scotton 2002; Haspelmath 2009: 40-41; Poplack 2018: 2). A similar approach has been adopted for the analysis of multilingual practices from a historical perspective (e.g., Pahta, Skaffari \& Wright 2018).

Classifications of borrowings tend to be complex and refined, but four basic types of borrowings are usually distinguished: loanwords, loan blends, loan translations, and semantic loans (Durkin 2009: 134), of which loanwords are the most frequent. Boyar, copeck, kolkhoz, maskirovka, proletkult, sputnik, ukase, and zek exemplify Russian loans attested over half a millennium of EnglishRussian language contact. ${ }^{3}$ Characteristically, they are rarely recorded in only one spelling. The need to transliterate Russian words from the Cyrillic into the Latin alphabet has necessarily produced a range of variants (e.g., droshky, drosky, droitzschka, drojeka, droshka, droshke, droshki, droska, and droskcha). Sometimes peculiarities of form suggest that the borrowing process was filtered through major languages, such as German (e.g., nitschewo) or French

The first Russian loanwords in OED3, boyar, tsar, and verst, are dated to 1555. A history of language contact between English and Russian is covered by Podhajecka (2013) and Eddy \& Proshina (2016). 
(e.g., koumiss), but one may also observe influences between Russian and minor languages (Podhajecka 2018: 144-145). ${ }^{4}$

Foreign forms and meanings of peripheral rather than core concepts, or "cultural borrowings" as Myers-Scotton (2006: 212) would have it, are perceived as vehicles of cultural transmission able to cross "ethno-linguistic boundaries with relative ease" (Hoogervorst 2018: 516). They often exhibit symbolic associations, either positive or negative, with the donor culture. For example, terms reflecting the Soviet regime such as gulag 'a prison camp, esp. for political prisoners' and psikhushka 'a psychiatric prison, esp. for Russian dissidents' have strongly pejorative connotations. ${ }^{5}$ According to Benson (1962: 42, 45), Russianisms in American newspapers, including those used "to a strictly American setting with little or no stylistic coloring", serve stylistic purposes (see also van Poucke 2011: 104). Benson's conclusions might perhaps be approached with caution, as many loans are evidently borrowed in order to name new concepts, but Durkin (2014: 379) would seem to corroborate them. He emphasizes that even vodka, widely known in the West, is marketed in a way that "typically plays on its Russian origin" (cf. Kabakchi 2013: 135).

\section{Resources and research methodology}

OED3, a dictionary based on historical principles, shows how English words have evolved throughout history. ${ }^{6}$ Each headword and each meaning is supported by a set of quotations arranged in chronological order from the earliest to the latest. Ideally, the first citation would provide the earliest recorded occurrence of the word in English, but this is not always the case, despite OED3's concerted efforts to update documentation for both old headwords and new (e.g., Gilliver 2005: 245-246). One of the goals of the revision is to collect antedatings, which are traced not only by the lexicographers, but also by the general public, for whom

$4 \quad$ Influences between Russian and Yiddish, so far limited to -nik, pogrom, and vigorish in OED3, may also be represented by $n u$ (Podhajecka 2020).

$5 \quad$ While gulag entered OED3 through the Oxford English Dictionary Additions Series (Simpson \& Weiner 1993), psikhushka remains ephemeral in English lexicography, having only been registered in The Second Barnhart Dictionary of New Words (1980) by Barnhart, Steinmetz \& Barnhart.

6 The first edition of the dictionary (henceforth, OED1), issued between 1884 and 1928, was followed by a one-volume Supplement (1933) and then a four-volume Supplement (19721986). The second edition (henceforth, OED2), consolidating the previously published material, appeared in 1989. Since 2000, the dictionary has been undergoing a top-to-bottom revision to update its historical documentation. So far, only the letter sections $\mathrm{M}-\mathrm{RZZ}$ and A-ALZ have been revised, but batches of entries from across the alphabet are added in quarterly intervals. In this way, the dictionary is a combination of OED2 and OED3. 
the "sport" of antedating (McKean 2007) has become an engrossing pastime. ${ }^{7}$ In the case of loans, this also means seeking attestations that contain the forerunners of words still unrecognized as English; since they appear in square brackets, they are called square-bracketed citations. Of course, discovering textual attestations is one thing, but establishing their value for OED3 is another.

Appearing first in the Oxford English Dictionary Additions Series (Simpson \& Weiner 1993), a modest supplement to OED2, the entry for nyet was incorporated in OED3 in 2004. Since the senses of the headword were both antedated and postdated, one may safely assume that the lexicographers worked with up-to-date historical records. My research indicates, however, that nyet appeared in English much earlier than claimed in OED3. With the proviso that the focus be on the form alone, the earliest attestation predates the first sense of nyet by nearly a hundred years; the second by more than ninety; and the third by at least two. ${ }^{8}$ What needs to be emphasized is that the searches yielded not only single hits, but rather that there is substantial diachronic evidence showing how nyet has spread through the English language.

I took into account archival text collections representative of $\mathrm{BrE}$ and $\mathrm{AmE}$, including (American) Historical Newspapers, the British Newspaper Archive, and Google Books. ${ }^{9}$ Google Books provides access to rich collections of 18thcentury material (Durkin 2014: 314) and, as my own research indicates, 19th- and 20th-century resources are equally extensive. Since the language of the press was the main port of entry for a great many borrowings (e.g., Carstensen 1965; Schultz 2013: 47; Saugera 2017: 108), the newspaper archives were of particular interest. ${ }^{10}$ In fact, my working hypothesis was that nyet may have entered English via journalistic texts.

7 The general public was also involved in the compilation of OED1. In 1879, James Murray issued "An Appeal to the English-speaking and English-reading Public to read books ..." (Gilliver 2016: 114). The response was most gratifying, as more than 2,000 volunteers from all over the world sent to Oxford "millions of quotations" collected from the books they read (Murray, cited in Ogilvie 2013: 61).

8 A possible antedating is found in Robert Nathan's The Innocent Eve: "But Mr. Nyet [i.e., Nyet Pradjadihop] disagreed." "If two countries had it," he declared, "they would soon be at war with each other, to establish their superiority" (1951: 135). It cannot be established beyond all doubt whether this usage has specifically Russian connotations.

9 I used the entire Google Books database because the British and American corpora available from Mark Davies's website (https://googlebooks.byu.edu/), downloaded from Google Books n-grams, include only a proportion of the data.

10 The same texts were often reprinted by different newspapers, so I used the chronologically earliest ones. Hal Boyle's article on Russia's nyet men, for example, appeared under various headlines throughout the United States. The American Newspapers Archive provides 117 matches for the May 1 issues, 24 for May 2 issues, 6 for May 3 issues, and 4 matches for May 8 issues. 
Neither the search procedure nor the interpretation of the results, however, was unproblematic. Firstly, it was often unclear whether the attestations constituted relevant evidence, i.e., genuine antedatings and square-bracketed citations, or irrelevant evidence because of the fuzzy borders between the two; fuzzy borders are typical of real language use. Secondly, searching for short lemmas was extremely time-consuming, all the more so in that the quality of optical character recognition (OCR) was a serious hindrance in finding relevant matches. Table 1 below shows the search results from the six largest archival collections.

Table 1. The number of hits for variant spellings of nyet in digital resources.

\begin{tabular}{|c|c|c|c|c|c|c|}
\hline Text Archive & nyet & nyets & niet & niets & njet & njets \\
\hline $\begin{array}{l}\text { (American) Historical } \\
\text { Newspapers }\end{array}$ & \multicolumn{2}{|c|}{73,934} & \multicolumn{2}{|c|}{507,270} & \multicolumn{2}{|c|}{34,847} \\
\hline British Newspaper Archive & \multicolumn{2}{|c|}{4,316} & \multicolumn{2}{|c|}{12,670} & \multicolumn{2}{|c|}{4,329} \\
\hline Chronicling America & 1,881 & 1,490 & 79,176 & 53,997 & 2,784 & 2,381 \\
\hline Google Books ${ }^{11}$ & 202 & 127 & 257 & 262 & 348 & 214 \\
\hline HathiTrust & 8,617 & 363 & 103,515 & 23,575 & 3,596 & 253 \\
\hline Internet Archive & 16,259 & 607 & 367,011 & 47,093 & 22,113 & 1,265 \\
\hline
\end{tabular}

The figures may be impressive, but they are grossly inaccurate because the distribution of nyet across historical texts is limited. There are two different reasons for this inaccuracy. On the one hand, numerous alleged occurrences of the Russianism are other words erroneously read optically. Searches in (American) Historical Newspapers, for instance, yielded yet, fleet, river, myself, west, and never (nyet/nyets); night, carpets, warmest, attorney, street, meet, wanted, and pieces (niet/niets); and subject, objected, house, Lennox, commerce, majesty, and next (njet/njets). Searches in the British Newspaper Archive returned rivetted, corn yet, livery, report, and eyes (nyet/nyets); Nye's, says, nice, quiet, and next (niet/niets); and net, buyers, safer, and Newport (njet/njets). On the other hand, many nyet forms are homographs retrieved from texts written in other languages, predominantly Dutch. Selecting specific time spans (e.g., 1800-1850) and using Boolean expressions (e.g., "nyet" "Russian") was helpful, but not always fully effective.

11 Standard searches in Google Books often yielded thousands of matches, but the results could not be verified because access was granted to a proportion of sources. In April 2019, Google Books ceased to provide the frequency data altogether, so the figures in Table 1 refer to the numbers of sources that may be browsed manually. 
Other corpora and text archives, such as the Corpus of Historical American English (COHA) or Time Magazine Corpus, confirmed the existence of the loanword over the last hundred years but provided no early citations. The first relevant instances of nyet and niet in COHA, for instance, come from the 1930s.

\subsection{Problems of interpretation}

In the past, lexicographers tried to differentiate between anglicized and nonanglicized words. James Murray, editor-in-chief of OED1, devised a complex scheme that divided words into four distinct classes: "naturals", "denizens", "aliens", and "casuals", of which naturals were native and fully naturalized words, denizens were words naturalized in use but not in form, aliens were names of "foreign objects or titles" with no native English equivalents, and casuals were "foreign words of the same class, but not in habitual use" (see also Ogilvie 2008: 6-7). The last three were marked with the symbol \|, known as "tramlines". Despite his conservatism in marking borrowings, Murray claimed that "if a word was used in an English context, it qualified as an English word" (Ogilvie 2013: 55-56), and he went to some lengths to include them in his dictionary. In line with the progress in lexicographical scholarship over the last decades, Murray's classification is no longer used in OED3. ${ }^{12}$ Still, it is worth asking under what circumstances a foreignism changes into an English word.

My methodology needed a framework into which the attestations could be integrated for an objective assessment. Ogilvie (2013: 175) provides a set of parameters (e.g., pronunciation, orthography, and variant forms), quotational evidence (e.g., italics, inverted commas, and glosses in brackets), and lexicographical treatment (e.g., labelling and square-bracketed citations) to evaluate a loanword in its dictionary context, but their applicability for this study is limited. Processes of loanword integration are dynamic and irregular, frequently involving a stage where different variants, both nativized and nonnativized, coexist (e.g., Winter-Froemel 2014: 66). Browsing through OED3, one sees that neither a word's foreign pronunciation, nor orthography, nor morphology needs to be an indicator of its alien status (e.g., Molokan, nitchevo, and papirosa). Thus, if we put aside the degree of adaptation and typographical marking as irrelevant, we are left with two key textual features: explanatory glosses and bilingual (mixed-language) contexts. ${ }^{13}$

12 This does not refer to the Oxford English Dictionary Additions Series (Simpson \& Weiner 1993), which retained the old-fashioned scheme. Since nyet was accompanied by tramlines, it was at best regarded as partially adapted. Ogilvie's (2008) article offers an interesting story of the "vanishing tramlines" in the 1933 Supplement to OED1.

13 I would like to extend my grateful acknowledgements to John Simpson, the former editor-inchief of OED3, for his helpful comments concerning the treatment of citations as reliable antedatings (p.c., May 2010). 
Explanatory glosses are not unusual insofar as speakers of the recipient language may reinforce the meaning of an unfamiliar word of foreign origin with its lexical equivalent or cultural counterpart (cf. Adams 2003: 30). Practices which involve constructing and negotiating meaning have a longstanding tradition in cross-linguistic encounters, even though, in writing, they usually take the form of a narrative. ${ }^{14}$ As Watts (2012: 1492) concedes, "language contact situations lie on a cline between the (assumed) mutual comprehensibility and the (assumed) mutual incomprehensibility of the interlocutors". This notwithstanding, citations clarifying the meanings of loanwords are not, as a rule, admitted into OED3, particularly as first citations, but there are exceptions to this rule (e.g., maskirovka, politruk, and starover).

Speaking of mixed-language contexts, OED3 requires loanwords to be used not only in an English text, but also in an English context. Lexicographers are thus ready to accept a word as a bona fide Russianism as long as it is not put into the mouths of non-English speakers. Durkin (2009: 174) points out, moreover, that we may speak of a continuum of cases from the explicit identification of a word as belonging to a foreign language (e.g., "This is a type of bread which they call in Italian focaccia"), to uses with reference to a foreign culture but without explicit identification of the language (e.g., "On holidays we had sandwiches made with focaccia"), to uses with no apparent identification of the word's foreign provenance (e.g., "I think focaccia is a good type of bread"). Even though he admits that a systematic distinction is difficult to apply "with any consistency" (Durkin 2009: 174), and despite OED3's illustrative examples failing to conform to the above principle (cf. the 1930 citation for narod, the 1960 citation for nilas, and the 1934 and 1957 citations for nyet), analysis of the contexts was a crucial element of my study.

\subsection{The entry for nyet in OED3}

According to OED3, nyet, also recorded under the spellings niet and njet, functions as an adverb and a noun. The former is defined as 'NO $a d v{ }^{2}$ and int.; denoting a blunt refusal or dismissal (frequently in representations or imitation of Russian speech), esp. on the part of Russia or (formerly) the Soviet Union'. The latter has two senses: 1 . NO $n .{ }^{1}$ 'a blunt refusal or dismissal' and 2. Mr. Nyet 'any person (esp. a politician in the Soviet Union) noted for having a negative or uncompromising attitude'. The adverb is dated to the 1920s and the nouns to the 1950s.

14 See, e.g. "Their drinke is like our peny Ale, and is called Quass" (OED3's entry for kvass) and "Their shoubes or gownes are hayrie on the outside, and open behinde, with tailes hanging downe to their hammes" (OED3's entry for shooba). Of these two citations, the former is dated to 1556 and the latter to 1598 . 
OED3's earliest attestation is a square-bracketed citation taken from George Kennan's Siberia and the Exile System (1891):

(1) ["Nyet brátushka (No, my little brother), you may walk goose-fashion with the priest... but you can't harness my horses goose-fashion"].

It comes from the London edition, but an American edition appeared in New York in the same year.

The first citation proper was found in Hallie Flanagan's Shifting Scenes of Modern European Theatre, published in 1928 in London:

(2) "Nyet! Nyet!" say I haughtily, having been informed of the droshky game".

It should be noted that many citations in OED3 are shortened due to limited space and this is the case with Flanagan. Upon closer scrutiny, the loanword occurs in a mixed-language context and it is nigh impossible to establish who exactly articulated the words:

(2a) "Nyet! Nyet!" He always exclaims with injured dignity. "Dwa rouble!" "Nyet! Nyet!" say I haughtily, having been informed of the droshky game".

The first nominal usage is found in Frank Howley's Berlin Command (1950):

(3) "Both my French and British colleagues pounced on this suggestion as a way out. But not the Russians. They responded with a definite "nyet!"”.

Here, too, there is a slight discrepancy between lexicographical principles and practice; nyet in the quotation above appears with an English indefinite article, but it was clearly verbalized by native speakers of Russian.

The first recorded occurrence of Mr. Nyet is traced to The Times of October 4, 1958:

(4) "Some cartoons from Iron Curtain countries, and these, being less familiar, are on the whole more interesting. It is odd, for instance, to see in a cartoon of "Mr. Nyet" not Mr. Khrushchev but Mr. Dulles".

In this case, the dating is incorrect - the quotation comes from October 14, 1958.

These first citations have been drawn from British (examples (1), (2), and (4)) and American publications (example (3)). The lexicographical status of two of them is somewhat debatable and this requires an explanation. OED3's policy, as John Simpson explained to me, is to treat every occurrence on an individual basis. 
The editors work with sets of quotations available from their reading programs and other digital resources, but these may include borderline cases that are hard to classify neatly. In such cases, they publish what they find most accurate, but are ready to incorporate better attestations when they come to light.

\section{Attestations for nyet from digital resources}

The evidence given below is divided into two parts. These parts deal with citations for nyet as an adverb (Section 4.1) and as a noun (Section 4.2). They are reproduced in the original typography.

\subsection{Nyet as an adverb}

In what follows, twenty-five attestations for the adverbial sense of nyet are provided in strict chronological order. They cover a period of one hundred and thirty-four years.

Jean-Baptiste-Barthélemy de Lesseps's Travels in Kamtschatka, during the Years 1787 and 1788, vol. 2 (London: Printed for J. Johnson):

(5) "English: no / Russian Niétt / Kamtschadale Biinakitlik" (1790: 390);

Robert Lyall's The Character of the Russians, and a Detailed History of Moscow (London: Printed for T. Caddel): ${ }^{15}$

(6) "When a husband returns from his affairs, and finds his wife thus laid up, while laughing, he addresses her in the mildest language "Shto ti Milinka; ti napilas," "What my dear! Thou art tipsey." And she replies in the tone of disease "Nyet u menya golova bolit," "No, I have a head-ache;" and there is no more said about the matter" (1823: cxix);

Ebenezer Henderson's Biblical Researches and Travels in Russia, Including a Tour in the Crimea, and the Passage of the Caucasus ... (London: Published by J. Nisbet):

(7) "xvi.1. ... the Vul. bonorum meorum non eges, and with which the Slav agrees, are thus given in the Russ: niet mnie blag kromie Tebia, "There is no good to me besides thee" (1826: 126);

15 Fragments of the text were also reprinted in The London Quarterly Review, vol. 31, December 1824-March 1825 (1825: 158). 
Friedrich Tietz's St. Petersburgh, Constantinople, and Napoli Di Romania, in 1833 and 1834: A Characteristic Picture Drawn during a Residence (New York: Theodore Foster):

(8) "The Russian now becomes, we might almost say, more courteous, as his reply indicates. "O, Batuschka, (little father, an appellation which in friendly converse he prefers to sir), Batuschka, that is too little!" One quits the shop; the Russian follows, and cries, "Give twenty roubles, Batuschka." "Ia bolsche niet dam, niet adin kopek!" (I will not give more, not a single kopek)" (1836: 38);

Robert Bremner's Excursions in the Interior of Russia: Including Sketches of the Character and Policy of the Emperor Nicholas, Scenes in St. Petersburg, etc., vol. 2 (London: Henry Colburn):

(9) "Seldom indeed is the negative njet, njet, "no, no," heard on these occasions; for they are much more quick at understanding them than most nations" (1839: 142);

Emmeline Stuart Wortley's “A Voyage in a Russian Steamer to St. Petersburg, October, 1853" printed in the Illustrated London Magazine: A Monthly Journal of Literature and Art, vol. 3 (London: Piper, Stevenson \& Spence):

(10) "Niet, niet, Papenka" (No, no, little papa)" (1855: 76);

Robert Harrison's Notes of a Nine Years' Residence in Russia, from 1844 to 1853 (London: T. Cautley Newby):

(11) "Nyett Vasha Imperatorsky Veleetchestva! "No, your Imperial Majesty," was his simple answer, for which his comrades jeered him not a little, as letting slip an opportunity of promotion, which a witty reply might have procured him" (1855: 224);

George Augustus Sala's A Journey due North: Being Notes of a Residence in Russia (Boston: Ticknor \& Fields):

(12) "And now I, on my part, understood why the Ischvostchiks had wished me to pay for them, and cried, "Nietts Geyde! Nietts Geyde!" for, from the pitching my luggage viciously into the hall ... and gave them no moreperhaps a little less - than their fare" (1858: 311); 
"Camping out in Siberia" printed in Putnam's Magazine, New Series, vol. 2, September 1868 (New York: G. P. Putnam \& Son): ${ }^{16}$

(13) "Well," replied the snowy figure standing waist-high in the drift. "Amerikanski nyett dobra kiour, eh?" (American no good driver). "Nyett sofsem dobra" was the melancholy reply as I waded out" (1868: 261);

[Lucy Hamilton Hooper's] The Tsar's Window (Boston: Robert Brothers):

(14) "A servant entered at the same time with lights, but I motioned him away and said, "Nyett," and he left me with only the firelights and the fastwaning day" (1881: 179);

Edward Rae's The White Sea Peninsula, a Journey in Russian Lapland and Karelia (London: John Murray):

(15) "He explains to the crowd that I am a Norwegian: when I correct him mildly, he says: Niet, niet, Anglitchânin" (1881: 161);

John Osmaston's Old Ali, or, Travels Long Ago (London: Hatchards):

(16) 'Beard shook his head, 'Niett, niett,' he said. 'Oh! Not yet; all right,' said I. 'I'll wait then.' I waited. 'Niett, niett,' again said Beard” (1881: 127);

Edward Tracy Turnerelli's A Russian Princess and a Russian Ghost Story: Two Historical and Personal Narratives (London: H. Blacklock):

(17) “The Generalshy has not yet risen, I suppose?" "Nyett, barinn-No, master" (189-: 140);

John Lloyd Warden Page's In Russia Without Russian: Being the Wanderings of an Englishman in Central Russia, by Land and Water (Plymouth: Bowering/London: George Routledge \& Son):

(18) "The purchaser affects to be shocked. "Pyait—five," he suggests. "Nyetno," returns the shopman. If the purchaser is very anxious to acquire the article, he raises his offer a rouble or two. Still "nyet" from the vendor" (1898: 49);

16 The text appeared later in George Kennan's Tent-life in Siberia and Adventures among the Koraks and Other Tribes in Kamtchatka and Northern Asia published in 1870 by the New York-based G. P. Putnam \& Sons. 
Frederick Whishaw's The Tiger of Muscovy (London-New York: Longmans \& Green): ${ }^{17}$

(19) "Now that you know this, you may return and tell her." "Nyet, nyet!" said Amy again, "the Queen did not know, and I did not know, that the Tsar is like one of his own medvedyi!" (1904: 88);

George Hornton's The Edge of Hazard (Indianapolis: The Bobbs Merrill Company): ${ }^{18}$

(20) "Tell him 'nyet!'," came the reply, and the American shook the hands of the captain and his two kind-hearted officers vigorously, repeating many times:- "Nyet! Nyet! Nyet! Nyet!" And thus he learned his third Russian word" (1906: 97);

Eliza Ruhamah Scidmore's As the Hague Ordains: Journal of a Russian Prisoner's Wife in Japan (New York: H. Halt):

(21) "America did not smell of leather or garlic that day. Niet. Niet. How that close warehouse on the dock smelled of low-tide and horses!" (1907: 20);

Marjorie Colt Lethbridge's Russian Chaps (London-New York: John Lane):

(22) "High praise, this, from John, son of John! Ivan Ivan'ich did not consider the proposal favourably. "Nyet," he said with emphasis" (1916: 85);

Lincoln Steffens's "What Free Russia Asks of Her Allies" printed in Everybody's Magazine 37A, July-October 1917 (New York: The Ridgway Company):

(23) "There always some voices clamored for blood. But always also some voice said: "Niet, niet. That's what the government did. We mustn't do any of the things the Government does. We must take the prisoners to the Duma and let them be tried" (1917: 135);

Donald C. Thompson's Donald Thompson in Russia (New York: The Century):

(24) “All he said was "niet." "Niet" in Russian means no" (1918: 24);

17 A portion of the book came to be reprinted in Longman's Magazine, vol. 44 (1904: 288).

18 As Coleman (2016: 83) tells us, the novel was republished in Britain under the title The Princess Romanova: A Tale of the Amur (1907). 
Olive Gilbreath's Miss Amerikanka: A Story (New York-London: Harper \& Brothers): ${ }^{19}$

(25) "Dasha had been coming and going with the tea-things, her nose and chin and eyes shining like the seraphim. "Nyet, Dasha. No samovar to-day" (1918: 91);

Oliver M. Sayler's Russia, White or Red (Boston: Little, Brown \& Company):

(26) "Several times I passed them, thinking they might have changed their minds, but always it was "Nietchevo, nyet!" an emphatic form of the negative" (1919: 48);

Alexander Zuev's John and Van'ka printed in The Living Age, vol. 313 (Boston: The Living Age):

(27) "Perhaps the children will rush upon the street and shout: "Van'ka, give us biscuits!" Then he will answer like John: "Niet, understand, niet! Finished" (1922: 772);

Clarissa S. Ware's “In Russia with Western Pioneers" printed in The Survey, vol. 49, October-March 1922/23 (New York: Survey Associates):

(28) "Then I turned on him and said one of my few Russian words, "nyit." It means a final no" (1923: 162);

Frank Harris's Contemporary Portraits: Fourth Series (New York: Brentano's):

(29) "Ignatief translates; Gorki, still drumming on the table with his right hand, answers curtly: "Nyet! Nyet!" The Kaiser would be more polite!" (1924: 177).

\subsection{Nyet as a noun}

Attestations for nyet as a noun have been divided into three subsections: nominal uses, attributive uses, and $M r$. Nyet. Taken together, this part of my database comprises twenty-three citations stretching over a century.

19 This novel was published for the sake of British readers as Russia in Travail (1918). It also appeared in volume 136 of Harper's Magazine (1917-1918). 


\subsubsection{Nyet (nominal uses)}

August von Haxthausen's The Russian Empire, Its People, Institutions, and Resources, translated by Robert Farie, vol. 1 (London: Chapman \& Hall):

(30) "If a stranger asks him, "Does so-and-so live in this street, and in which house?" a laconic "Niét!" (No) is the first answer" (1856: 60);

"Notes of a Tour from Moscow to the Crimea" (from special correspondent of The Times) printed in The Sun of January 6, 1857 (London):

(31) "We had a long gingling drive through any number of versts of muddy streets, and then a sudden halt at a huge and prison-looking building, at which our courier dismounted from his cold perch, and from which emerged a hairy-hooded moujik waiter, the staple of whose conversation was the eternal "Niet, niet" (No! no!)" (1857: 7);

Samuel Sullivan Cox's Arctic Sunbeams, or, from Broadway to the Bosphorus by Way of the North Cape, vol. 1 (New York: G.P. Putnam's Sons):

(32) "But, with a hasty push and an impetuous "Niett! "Niett!"—(no, no)—our papers were confiscated to the state" (1882: 220);

Temple Bar: A London Magazine for Town and Country Readers, vol. 80, MayAugust 1887 (London: Ward \& Lock):

(33) "She is too late with her " $N$ 'yet! N'yet!" Tatyana's cigarette is between the two ominous fingers, and have her say she will" (1887: 67);

Francis Edward Clark's A New Way around an Old World (New York-London: Harper \& Brothers): ${ }^{20}$

(34) "At last a peasant, in Russian blouse and top-boots, appeared who seemed to belong to the establishment; but, alas! He spoke a word of naught but Russian. To polyglot inquiries: "Do you speak English?" "Sprechen Sie Deutsch?" "Parlez-vous français?" he responded with a "nyet," and a helpless shake of the head" (1901: 88);

20 The book was later republished in London as The Great Siberian Railway: What I Saw on My Journey (1904). 
Francis McCullagh's "Fall of Port Arthur May Demoralize Russian Army" printed in The St. Louis Republic of August 14, 1904 (St. Louis, Missouri):

(35) "I went from one of these hotels to another, wearily looking for a room, but in the first three I met with such an indignant "nyet" that I wondered what on earth I had done" (1904: 10);

Lester Cohen's Two Worlds (New York: Covici \& Friede):

(36) "With a snort she marched into the aisle, I stood at the compartment door, watching. After a string of nyets, she gave up on Bachmatch, asked if there was a restaurant car" (1936: 158);

Haruko Ichikawa's Japanese Lady in Europe (Tokyo: Kenkyusha):

(37) "Flatly rebuffed with a "Nyet!," he said, "Spaseebo" (Thank you), adding reverently, in Japanese, "Not at all" (1937: 61);

Eve Curie's Journey among Warriors (Garden City-New York: Doubleday \& Doran):

(38) "But now-now there was no more danger that armed soldiers would knock on my door and threaten to arrest me by mistake. Now I no longer heard the "niet" (no) of the Moskva telephone girl when I asked her for some butter or meat" (1943: 221).

\subsubsection{Nyet (attributive uses)}

The digital resources also provide instances whereby nyet is applied attributively. Examples include nyet approach, nyet attitude, nyet girl, nyet history, nyet man, nyet woman, nyet negotiator, nyet position, nyet sayer, and nyet vote, of which nyet man is both the earliest and the most frequent use.

Hal Boyle's article printed in The Port Huron Times Herald of May 17, 1948 (Port Huron, Michigan): ${ }^{21}$

(39) [Title] "Farewell to the 'Nyet' Man" (1948: 4);

"Stalin's 'Maybe'?" (Christian Science Monitor) printed in The Greenville News of August 29, 1948 (Greenville, South Carolina):

21 Another incarnation of Boyle's article appeared as "World's Greatest 'Nyet' Man Rates Most Colorful in UN" (The Santa Fe New Mexican of May 18, 1948). 
(40) 'Once again Premier Stalin has intervened in a deadlock between Russia's 'nyet man' and the Western envoys at Moscow. In a meeting nearly five hours long, East-West negotiations, with Russia's top man at the head of the table, have transmuted the Molotov 'No' into the Stalin 'Maybe", (1948: 4);

"Vishinsky Balks" printed in The Akron Beacon Journal of June 1, 1949 (Akron, Ohio):

(41) "The "Nyet" man is back. Russia's Foreign Minister Vishinsky has turned thumbs down on the western allies' plan for unifying Germany" (1949: 6);

"New Soviet Line-Up Stirs Conjecture" printed in The Gazette of March 7, 1949 (Montreal, Canada):

(42) “Also, Vishinsky's former post of First Deputy Foreign Minister has been allotted to Andrei Gromyko, the Soviet's outstanding "nyet" man in the Security Council" (1949: 8);

Town \& Country, vol. 105 (New York: Hearst):

(43) "The admirers of M. Black, actually legion and world-wide, credit him with so cosseting Molotov during the early Big Four conferences of foreign ministers at the Waldorf-Astoria that the big nyet man actually forgot himself long enough to say $d a$ to the Italian peace treaty" (1951: 132);

Robert Ruark's article printed in The Coos Bay Times of November 13, 1952 (Marshfield, Oregon):

(44) [Title] "Nyet' Man and Counter-Irritant Use in Cabinet, UN suggested" (1952: 4);

Newsweek of January 10, 1955, vol. 46, part 1 (New York: Newsweek):

(45) "The blustering nyet men of Soviet diplomacy are a thing of the past" (1955: 38);

U.S. News and World Report, vol. 39 (Washington, DC: [s.n]):

(46) "One of these is Foreign Minister V.M. Molotov, who can quibble all day over the meaning of a word: the other is Deputy Foreign Minister Andrei Gromyko, who is destined for a place in history as Russia's "Nyet" man at the United Nations" (1955: 12); 
Hal Boyle's "Red Hallelujah Men Still Going Strong" printed in The Ithaca Journal of May 1, 1956 (Ithaca, New York):

(47) "An optimist might hope that Shelepin's attack presaged the fall of the old "Hallelujah men" and that the emergence of a new class of "nyet men," sturdy men of conscience who would have the courage to say "no!" loudly and clearly to whatever they thought was wrong" (1956: 6).

\subsubsection{Mr. Nyet}

The other nominal sense, a later newcomer in English, takes the form of $M r$. Nyet ${ }^{22}$ sometimes expressed as Mister Nyet ${ }^{23}$ Citations documenting this come from a handful of sources.

"Vyacheslav M. Molotov Fanatic in His Devotion to Stalin" (Reuters) printed in The Windsor Star (Ontario, Canada) of June 2, 1956:24

(48) "Mr. Niet, Niet" (No, No), as he was known in the West, held key posts in the top ranks of the Soviet Union longer than any other member of the present leadership. He had worked with Lenin, served as Communist Party chief, was premier, and had two periods as foreign minister" (1956:21);

Coronet, vol. 41 (Chicago: David A. Smart):

(49) "As the alchemy of American convention and custom worked on him, his independence increased. "Mr. Niet," I began to call him. A polite, meekmannered little man, his soft but firm "niet" (Russian for "no") revealed a will of steel that had helped him survive four decades of war, prison, poverty and D.P. camps" (1956-1957: 36);

Foreign Relations of the United States, vol. 27 (Washington, DC: US Government Printing Office):

22 Parallel to this is Mrs. Nyet, of which James Kelly's report is a suitable example: "So stubborn is she on occasion that some diplomats have dubbed her "Mrs. Nyet" (Time of September 7, 1981).

23 The earliest occurrence in my sources comes from April 5, 1958: "He holds the world record for veto votes in U.N., is famous for walkouts there and is "Mister Nyet" himself" (e.g., The Morning Herald from Hagerstown, Maryland). Other variant spellings, Mister Niet and Mister Njet, are also attested in texts, but far less frequently.

24 Another version of the article was printed in Belfast News-Letter of June 2, 1956, and still another in Australia's The Sydney Morning Herald of June 3, 1956. 
(50) "In this regard, in a recent speech before the French Senate he characterized himself as "Mr. Nyet". Thus it is unthinkable that in making up its 1957 budget the French Government would consider any increase in its NATO defense effort" (1955-57: 80);

The Economist, vol. 179, part 2: April-June 1956 (London: Economist Newspaper):

(51) "His stolid negative performances during the cold war gained Mr Molotov the international nickname of Mr Niet. Within the Soviet bloc this was also the period when Stalin peremptorily ordered his satellites about, apparently hurting Mao Tse-tung's feelings and bringing about the break with Marshal Tito" (1956: 1002);

The Knoxville News-Sentinel of February 17, 1957 (Knoxville, Tennessee):

(52) "Andrei Gromyko, Russia's new foreign minister, is the original Mr. Nyet. That means "no" in Russian" (1957: 8).

\section{Discussion}

Closer scrutiny of the textual evidence reveals details of the early transmission of nyet into English. It covers forty-eight passages excerpted from books, mainly travel accounts, magazines, and daily newspapers. It seems that the loanwords are specific to these text types due to their emphasis on informative and entertaining content. It is worth adding that I intuitively expanded the searches to other spellings. In addition to the graphic variants listed in OED3, I came across nyit, a rarity; nietts, another nonce occurrence $;{ }^{25}$ two alternatives ending with a double $t$ (niett and nyett); and one spelled with a diacritic ( $n^{\prime} y e t$ ), presumablyalbeit wrongly — considered a mark of palatalization. ${ }^{26}$ These forms account for $18 \%$ of all the occurrences in my database. As unassimilated, they were restricted to the first century (1790-ca. 1890) of the word's history, but they co-occurred with the anglicized spellings throughout the timespan.

25 The spelling nietts is less idiosyncratic than might seem at first sight. Reiff (1869: 38) and Spalding, the translator of Pushkin's Eugine Onéguine (Pushkin 1881: 261), tell us that Russians used the words sudar' 'Sir' and sudarynja 'Madam' contracted to -s to show respect to their interlocutors; hence das 'yes, Sir/Madam' and nyets 'no, Sir/Madam.

26 Russian vowels of the so-called "soft series" (я, e, ë, ю) soften preceding consonants in words such as кухня /kuxn $\mathrm{j} a /$, няня $/ \mathrm{n}^{\mathrm{j}} \mathrm{an} \mathrm{j} \mathrm{a} /$, and нет $/ \mathrm{n}^{\mathrm{j}} \mathrm{et} /$ (e.g., Aizlewood 2007: 8). Since the mark of palatalization $\left({ }^{j}\right)$ was transcribed into English as $i, y$ or $j$, as in niet, nyet, and njet, there was no need to employ a diacritic. 
Passages with explanatory glosses are easy to establish. In a handful of cases, one encounters whole Russian utterances translated into English, whereas in others nyet alone is paired with 'no', the prototypical English equivalent. There are also a number of instances which appear in mixed-language contexts. It was sometimes hard to tell, at least within brief passages, whether nyet was from the mouth of native or non-native speakers of English, so analyses of more extensive contexts were necessary. In some cases, the word occurs both with a gloss and in a foreign context.

A few of the earliest attestations should be dismissed. (5) registers a Russian word transliterated into the Roman script from a six-language glossary. This cannot be accepted. The foreign "side" of bilingual or multilingual glossaries or dictionaries represents insufficient evidence. (6)-(11) are both glossed and used in bilingual contexts with a substantial degree of Russian identification. (12) is put into the mouth of Russians, while the following one features two insertions of Russian text. The status of (14), in which an Englishman resorts to nyet to communicate with a servant, is open to interpretation. (15) resembles OED3's square-bracketed citation and there is every indication that it could be treated as one. The word in (16) is enunciated by a stereotypical Russian, whereas (17) and (18) are again glossed. (19) looks promising; the English protagonist named Amy uses nyet, but she does so to reinforce her message. As a result, we may treat her nyet and medvedyi either as code-switches or borrowings. Nyet in (20), (22), (26), and (29) is understood explicitly as a foreign word. (21) and (23) are similar in that niet is felt to be foreign, but it conveys a pragmatic effect typical of loanwords, while the meaning in (24) is clarified. (25) and (27) are regarded as antedatings proper; despite pertaining to Russian cultural realia, i.e., Dasha and samovar in (25) and Van' $k a$ in (27), the loans are ascribed to non-Russian speakers. (28) is glossed, so it falls short of the criteria for indisputable antedatings.

Nyet in (30)-(32), while accompanied by different English modifiers (laconic, eternal, and impetuous), is also glossed. Examples (33)-(37) include indirect references to Russian, thus exhibiting a certain degree of validity, while the loanword in (38) is again juxtaposed with 'no'. By contrast, all the attributive uses, i.e., (39)-(47), are wholly relevant. Regarding the attestations for the occurrence of Mr. Nyet, (48) comes with an explanatory gloss, whereas (49) is partly glossed, but since Mr. Niet itself is not remarked upon, it is reasonable evidence. The last three examples are useful as antedatings for OED3's entry.

Analysis of the online resources allowed me to make additional observations. Nyet man frequently appeared in American newspapers in the 1950s and the $1960 \mathrm{~s}$, as did nyet men and nyet people, referring metonymically to various 
groups of people, usually Russians. ${ }^{27}$ In five out of the nine instances above, nyet man is not yet treated as a fixed phrase, but there is some diachronic development. In 1948, the American journalist Hal Boyle referred to nyet man (39) and eight years later to nyet men (46). In fact, this use of nyet is not quite a novelty; Ayto (1999: 355) provided a 1957 citation from Time, while Bryant (1967: 23) found nyet-man and nyet-people in the 1963 issue of The Saturday Review.

It is worthy of mention that the entry for nyet in the Oxford English Dictionary Additions Series (Simpson \& Weiner 1993) included information that the loan may be used attributively, illustrating it with a 1957 citation featuring nyet man. It was the only element omitted when the entry was incorporated in OED3. The diachronic data for nyet man and other phrases mentioned in Section 4.2.2 are not abundant, but the usage is nevertheless sufficiently frequent to find its way back into the dictionary material.

Interestingly, Andrei Gromyko, Soviet Minister of Foreign Affairs, was one of the Russians who earned the nickname $M r$. Nyet, ${ }^{28}$ and the first quotation documenting that fact comes from 1957. This stands in stark contrast to Gromyko's biography from Wikipedia, which reports that "Western pundits" called him $M r$. Nyet as early as the 1940s. Citation (39) seems to resolve this puzzle, as Gromyko was dubbed nyet man as early as 1948. Of course, nyet man and Mr Nyet are by no means synonymous forms, but both are built on nyet with its strong expressive meaning and both have become elements of the English political lexicon.

Nyet is often accompanied by its English counterpart. Fourteen passages in my database include intertextual glosses either in brackets, inverted commas, or double quotation marks, with the span of usage covering an impressive eighty-four years for the adverb and eighty-seven for the noun..$^{29}$ The pattern of glossing Russian words, however, is not confined to early uses and has recurred in 20th-century English texts. ${ }^{30}$ Explaining the need to clarify the meaning of nyet, arguably

27 Later usage may be illustrated by the following citations: "the Soviet press operation consisted of nyet men in gray suits" (Newsweek of March 31, 1997), "panel of Nyet men in mother Russia" (The Schuyler Sun of June 14, 1984), and "the typical Soviet nyet people" (Tomas Venclova's Forms of Hope: Essays, 1999: 262).

28 More recently, it was also used for President Vladimir Putin (e.g., "The return of Mr Nyet", The Economist of July 17, 2008) and the Russian Defense Minister Sergei Ivanov (e.g., "He speaks fluent English and Swedish and possesses a natural talent for changing from "Mr. Nice Guy" into "Mr. Nyet", Eurasia Daily Monitor of November 28, 2005).

29 The first glossed occurrence of nyet as an adverb comes from (9) and the last from (28), whereas the first glossed occurrence of nyet as a noun comes from (30) and the last from (38).

30 The pattern may be illustrated by the following examples: "I've been getting help," he said. "I've learned da, which means yes, and nyet, which means no, and a few other words" (The Miami News of January 15, 1976); "As they explained patiently, that meant that she would have to cross out the "nyet," or "no," on the ballot" (The New York Times of April 26, 1993), and "Then Gorbachev said one Russian word: "Nyet." No" (Ken Follett's Edge of Eternity, 2014: 1039). 
intelligible to at least some English speakers, is fraught with difficulty. The best educated guess is that the processes of lexical integration and the accommodation of a loanword are far more heterogeneous than has been assumed. Neither may one exclude the possibility that some extralinguistic motives come into play, compelling the writers to choose one discursive strategy over another.

It is generally assumed that bilinguals, i.e., users with proficiency in both the donor and the recipient languages, are conduits of borrowing (e.g., Field 2002: 186; cf. Weinreich 1970: 71-82; Görlach 2008: 715; Matras 2009: xiii; Thomason 2013: 286). Some of the authors quoted here, however, must have had a limited knowledge of the Russian language. ${ }^{31}$ A majority of 16th-century borrowings were transferred into English by merchants of the Muscovy Company, whose expertise in Russian affairs was not always accompanied by "expertise in the language" (Pennington 1967: 780). A multitude of misspellings recorded in 19th- and 20th-century travelogs suggest that the knowledge of Russian exhibited by other English-speaking travelers was likewise superficial. The conclusion that can be drawn from this is self-evident: imperfect bilinguals, or "pseudobilinguals", to use the term coined by Peal \& Lambert (1962: 6), may also be regarded as agents of contact-induced change.

\section{Conclusions}

The purpose of this paper has been to investigate how nyet came into English and whether the data brought to the fore might help antedate the first citations in OED3's entry. One new finding is the long history of attestation in English the word enjoyed, gradually morphing from an item inserted in chunks of foreign text to a loanword. Many instances of nyet are accompanied by glosses or occur in purely Russian contexts, which, even regardless of the word's anglicized form, provides dubious evidence. The material presented in Section 4, however, offers nine partly suitable and thirteen fully suitable antedatings, ${ }^{32}$ so we may expect that some of them will be adopted by OED3's editors. A few others, including examples (10), (11), and (15), are good candidates for square-bracketed citations.

Of the forty-eight attestations of nyet given above, fourteen come from British sources, four from both British and American sources, and as many as twentyseven from American books, journals, and newspapers, which sheds new light on

31 For example, ia niet dam in Example (8) would have been expressed in Russian as я не дам and Nyett Vasha Imperatorsky Veleetchestva in Example (11) was originally Russ. Hem, Ваше Императорское Величество.

32 As could be expected, they appeared relatively late. For instance, out of the attestations for the adverbial sense of nyet, (25) and (27) are the first to be considered fully suitable. 
the role AmE has played in the history of this loanword. ${ }^{33}$ My assumption that there was little geographical variation proved correct: only two citations, (42) and (48), represent Canadian English (CanE), while (37) comes from a book published in Tokyo. Mapping the route of transmission is straightforward: up to the mid-20th century, London was practically the sole port of entry for BrE, whereas cities on the East Coast, primarily New York, Boston, and Washington, $\mathrm{DC}$, functioned as the main gateways for AmE. They may be perceived as centers of text circulation networks from which lexical innovations, including loanwords, spread to the peripheries of the English-speaking world.

According to Mencken (1921: 202), many loanwords entered AmE through New York thanks to the city's huge immigrant population. It would be interesting to explore whether the Russian diaspora in the United States had any impact on the transmission of nyet. After all, as has been stated by Eddy \& Proshina (2016: 17), "During five waves of emigration from Russia beginning in the 1850s, millions of Russian-speaking people emigrated for political, economic, and religious reasons, establishing Russian-speaking diasporas around the world, mainly in the United States, where at this time Russians make up $10 \%$ of the country's foreign-born population. ${ }^{34}$ For the time being, evidence for such a route of transmission has been non-existent, so this aspect requires further research.

My hypothesis that the loanword was taken into English by journalists is not entirely wrong, even though it is only pertinent for nyet man and Mr. Nyet. As the diachronic data in Section 4 show, from the mid-20th century onwards, nyet occurred almost exclusively in press materials, which dominated other text genres traditionally associated with foreignness such as travelogs. ${ }^{35}$ In any case, given the political tensions between the Russian Federation and English-speaking countries, it comes as no surprise that nyet is still visible in the press today: a search through the NOW Corpus (News on the Web), including texts from 2010 up until today, yields 220 relevant hits.

33 Corpora confirm the visibility of the loanword in AmE. COHA provides 50 hits for nyet and 16 for (Russian-derived) niet, while the Corpus of Contemporary American English (COCA) yields as many as 102 for nyet and 2 for (Russian-derived) niet. By contrast, a query in the British National Corpus (BNC) yields only 3 hits for nyet and 3 for niet, and slightly more tokens are found in the Hansard Corpus containing speeches given in the British Parliament (19 hits for nyet and 16 for niet). The distribution of variant forms in the Corpus of GlobalWeb Based English (GloWbE) indicates that nyet may be considered AmE and niet BrE.

34 On the other hand, the socially, economically, and politically dominant language (here, AmE) always exerts an influence on a subordinate language (here, Russian), which is ultimately lost among third-generation speakers (e.g., Baker \& Prys Jones 1998: 312). It is thus only natural that Russian immigrants appropriate words from AmE and these "become markers of adaptation to a new society-for example, но (pronounced [ $\left.{ }^{\mathrm{n}} \mathrm{no}\right]$ ) instead of нет" (Dubinina \& Polinsky 2013: 4; see also Benson 1957).

35 Moskowich (2019: 52) states that travelogs were in due time replaced by travel guides and documentaries. 


\section{REFERENCES}

\section{DIGITAL RESOURCES}

(American) Historical Newspapers. https://www.newspapers.com/ $\mathrm{BNC}=$ The British National Corpus. https://corpus.byu.edu/bnc/

British Newspaper Archive. https://www.britishnewspaperarchive.co.uk/ Chronicling America. https://chroniclingamerica.loc.gov/

COCA $=$ The Corpus of Contemporary American English. https://corpus.byu.edu/coca/

$\mathrm{COHA}=$ The Corpus of Historical American English. https://corpus.byu.edu/coha/

GloWbE = The Corpus of Global-Web Based English. https://www.english-corpora.org/glowbe/

Google Books. https://books.google.com/

Hansard Corpus. https://www.hansard-corpus.org/

HathiTrust. https://www.hathitrust.org/

Internet Archive. https://archive.org/

NOW Corpus (News on the Web). https://corpus.byu.edu/now/

The New York Times Archive. https://www.nytimes.com/

Time Magazine Corpus. https://www.english-corpora.org/time/

\section{OTHER REFERENCES}

Adams, James N. 2003. Bilingualism and the Latin language. Cambridge University Press. DOI: $10.1017 / \mathrm{CBO} 9780511482960$

Aizlewood, Robert. 2007. Routledge intensive Russian course. Routledge.

Ayto, John. 1999. Twentieth century words. Oxford University Press.

Baker, Colin \& Sylvia Prys Jones (eds.). 1998. Encyclopedia of bilingualism and bilingual education. Multilingual Matters.

Barnhart, Clarence L., Sol Steinmetz \& Robert K. Barnhart (eds.). 1980. The second Barnhart dictionary of new words. Barnhart Books.

Barros, Rita Queiroz de. 2018. Twentieth-century Romance loans: Code-switching in the Oxford English Dictionary? In Päivi Pahta, Janne Skaffari \& Laura Wright (eds.), Multilingual practices in language history: English and beyond, De Gruyter Mouton, 61-76. DOI: doi.org/10.1515/9781501504945-004

Benson, Morton. 1957. American influence on the immigrant Russian press. American Speech 32(4). 257-263. DOI: $10.2307 / 453974$

Benson, Morton. 1962. Russianisms in the American press. American Speech 37(1). 41-47. DOI: $10.2307 / 453994$

Brewer, Charlotte. 2013. OED online re-launched: Distinguishing old scholarship from new. Dictionaries: Journal of the Dictionary Society of North America 34. 101-126. DOI: $10.1353 /$ dic.2013.0002

Bryant, Margaret M. 1967. A selected list of compounds from present-day reading. Publication of the American Dialect Society 48(1). 1-32. DOI: 10.1215/-48-1-1

Carstensen, Broder. 1965. Englische Einflüsse auf die deutsche Sprache nach 1945. Carl Winter Universitätsverlag. 
Coleman, Brian. 2016. George Horton: The literary diplomat. Byzantine and Modern Greek Studies 30(1). 81-93. DOI: 10.1017/S0307013100015068

Derbyshire, William W. 1971. The lexical impact of Russian upon English. Russian Language Journal / Русский Язык 25(91). 41-50.

Dubinina, Irina \& Maria Polinsky. 2013. Russian in the USA. In Michael Moser \& Maria Polinsky (eds.), Slavic languages in migration, LIT Verlag. 1-28.

Durkin, Philip. 2009. The Oxford guide to etymology. Oxford University Press.

Durkin, Philip. 2014. Borrowed words. A history of loanwords in English. Oxford University Press. DOI: 10.1093/acprof:oso/9780199574995.001.0001

Eddy, Anna A. \& Zoya G. Proshina. 2016. Russian and English contact: Past and present. In Zoya G. Proshina \& Anna A. Eddy (eds.), Russian English. History, functions, and features, Cambridge University Press. 9-24.

Field, Frederic W. 2002. Linguistic borrowing in bilingual contexts. John Benjamins. DOI: $10.1075 /$ slcs.62

Fischer, Roswitha. 2010. Introduction: Studying anglicisms. In Roswitha Fischer \& Hanna Pułaczewska (eds.), Anglicisms in Europe: Linguistic diversity in a global context, Cambridge Scholars Publishing. 1-14.

Gilliver, Peter. 2005. Materials and methodologies for the New Oxford English Dictionary”. In Henrik Gottlieb, Jens Erik Mogensen \& Arne Zettersen (eds.), Symposium on Lexicography XI: Proceedings of the Eleventh International Symposium on Lexicography May 2-4, 2002 at the University of Copenhagen, Max Niemeyer Verlag. 241-248.

Gilliver, Peter. 2016. The making of the Oxford English Dictionary. Oxford University Press. DOI: 10.1093/acprof:oso/9780199283620.001.0001

Görlach, Manfred. 2008. Borrowing as language conflict. In Marlis Hellinger \& Anne Pauwels (eds.), Handbook of language and communication: Diversity and change, De Gruyter Mouton. 715-749. DOI: 10.1515/9783110198539.4.715

Grant, Anthony P. 2015. Lexical borrowing. In John R. Taylor (ed.), Oxford handbook of the word, Oxford University Press. 431-444. DOI: 10.1093/oxfordhb/9780199641604.013.029

Haspelmath, Martin. 2009. Lexical borrowing: Concepts and issues. In Martin Haspelmath \& Uri Tadmor (eds.). Loanwords in the world's languages: A comparative handbook, De Gruyter Mouton. 35-54. DOI: 10.1515/9783110218442.35

Hock, Hans H. 1991. Principles of historical linguistics (2nd edn.). De Gruyter Mouton. DOI: $10.1515 / 9783110219135$

Hoogervorst, Tom. 2018. Sailors, tailors, cooks, and crooks: On loanwords and neglected lives of Indian Ocean ports. Itinerario 42(3). 516-548. DOI: 10.1017/S0165115318000645

Kabakchi, Victor V. 2013. Russian-Culture-Oriented English (RCOE). Studia Linguistica: Язылк. Текст. Дискурс 22. 132-141.

MacSwan, Jeff. 2012. Code-switching and grammatical theory. In Tej K. Bhatia \& William C. Ritchie (eds.), The handbook of bilingualism and multilingualism (2nd edn.), Wiley Blackwell. 323-350. DOI: 10.1002/9781118332382.ch13

Matras, Yaron. 2009. Language contact. Cambridge University Press. DOI: 10.1017/CBO9780511809873

McDonald, Katherine. 2015. Oscan in Southern Italy and Sicily. Evaluating language contact in a fragmentary corpus. Cambridge University Press. DOI: 10.1017/CBO9781316218457 
McKean, Erin. 2007. What came first: The competitive sport of 'antedating'. The Boston Globe, October 14, 2007.

Mencken, Henry L. 1921. The American language: An inquiry into the development of English in the United States. A. A. Knopf.

Moskowich, Isabel. 2019. An introduction to CHET, the Corpus of History English Texts. In Isabel Moskowich, Begoña Crespo, Luis Puente-Castelo \& Leida Maria Monaco (eds.), Writing history in Late Modern English: Explorations of the Coruña Corpus, John Benjamins. 41-56. DOI: 10.1075/z.225.03mos

Myers-Scotton, Carol. 2002. Contact linguistics: Bilingual encounters and grammatical outcomes. Oxford University Press. DOI: 10.1093/acprof:oso/9780198299530.001.0001

Myers-Scotton, Carol. 2006. Multiple voices: An introduction to bilingualism. Wiley-Blackwell.

OED1 = Murray, James A. H., Henry Bradley, William Craigie \& Charles T. Onions (eds.). 18841928. The Oxford English Dictionary (originally published as A New English Dictionary on Historical Principles), vols. 1-10. Clarendon Press.

OED2 = Simpson, John \& Edmund S. Weiner (eds.). 1989. The Oxford English Dictionary (2nd edn.), vols. 1-20. Clarendon Press.

OED3 = Simpson, John \& Michael Proffitt (eds.). 2000-. The Oxford English Dictionary (3rd edn.). Oxford University Press. http://www.oed.com/

Ogilvie, Sarah. 2008. The mysterious case of the vanishing tramlines: James Murray's legacy and the 1933 OED Supplement. Dictionaries: Journal of the Dictionary Society of North America 29. 1-22. DOI: $10.1353 /$ dic.2008.0009

Ogilvie, Sarah. 2013. Words of the world: A global history of the Oxford English Dictionary. Cambridge University Press. DOI: 10.1017/CBO9781139129046

Pahta, Päivi, Janne Skaffari \& Laura Wright (eds.). 2018. Multilingual practices in language history: English and beyond. De Gruyter Mouton. DOI: 10.1515/9781501504945

Peal, Elizabeth \& Wallace E. Lambert. 1962. The relation of bilingualism to intelligence. Psychological Monographs: General and Applied 76. 1-23.

Pennington, A. E. 1967. A sixteenth-century English slavist. The Modern Language Review 62(4). 680-686. DOI: 10.2307/3723096

Podhajecka, Mirosława. 2013. Russian borrowings in English: A dictionary and corpus study. Wydawnictwo Uniwersytetu Opolskiego.

Podhajecka, Mirosława. 2018. Russian loanwords in the Oxford English Dictionary revisited. Przegląd Rusycystyczny 2. 133-158.

Podhajecka, Mirosława. 2020. Additional evidence for nu. American Speech 95(3). 364-376. DOI: 10.1215/00031283-7362206

Poplack, Shana. 2018. Borrowing: Loanwords in the speech community and in the grammar. Oxford University Press. DOI: 10.1093/oso/9780190256388.001.0001

Poucke, Piet van. 2011. Translation and linguistic innovation: The rise and fall of Russian loanwords in literary translation into Dutch. Trans ÜD. Arbeiten zur Theorie und Praxis des Übersetzens und Dolmetschens 39. 101-120.

Pushkin, Alexander. 1881. Eugine Onéguine: A romance of Russian life in verse. Translated from the Russian by Lieut-Col. Spalding. Macmillan.

Reiff, C.P. 1869. Little manual of the Russian language: A work in which the Russian words are represented with their pronunciation figured in English characters and with their accentuation (3rd edn.). Mausenneueve.

Saugera, Valérie. 2017. Remade in France: Anglicisms in the lexicon and morphology of French. Oxford University Press. DOI: 10.1093/acprof:oso/9780190625542.001.0001 
Schendl, Herbert. 2002. Mixed-language texts as data and evidence in English historical linguistics. In Donka Minkova \& Robert Stockwell (eds.), Studies in the history of the English language: The millennial perspective, De Gruyter. 51-78. DOI: 10.1515/9783110197143.1.51

Schultz, Julia. 2013. Twentieth century borrowings from French to English: Their reception and development. Cambridge Scholars Publishing.

Simpson, John \& Edmund Weiner (eds.). 1993. Oxford English Dictionary additions series, vols. 1-2. Clarendon Press.

Thomason, Sarah G. 2001. Language contact: An introduction. Edinburgh University Press.

Thomason, Sarah G. 2013. Innovation and contact: The role of adults (and children). In Daniel Schreier \& Marianne Hundt (eds.), English as a contact language, Cambridge University Press, 283-297. DOI: 10.1017/CBO9780511740060.016

Thomason, Sarah G. \& Terrence Kaufman. 1992. Language contact, creolization, and genetic linguistics. University of California Press.

Treffers-Daller, Jeanine. 2010. Borrowing. In Mirjam Fried, Jan-Ola Östman \& Jef Verschueren (eds.), Variation and change: Pragmatic perspectives, John Benjamins. 17-35. DOI: 10.1075/hoph.6.02tre

Tulloch, Joanna. 2002. 'Exotic' loans and their etymologies. Oxford University Working Papers in Linguistics, Philology \& Phonetics 7. 238-241.

Watts, Richard J. 2012. New perspectives, theories and methods: The actuation problem revisited. In Alexander Bergs \& Laurel J. Brinton (eds.), English historical linguistics, vol. 2, De Gruyter Mouton. 1490-1509. DOI: 10.1515/9783110251609.1490

Weinreich, Uriel. 1970. Languages in contact: Findings and problems. De Gruyter Mouton. DOI: $10.1515 / 9783110802177$

Winford, Donald. 2010. Contact and borrowing. In Raymond Hickey (ed.), The handbook of language contact, Wiley-Blackwell. 170-187. DOI: 10.1002/9781444318159.ch8

Winter-Froemel, Esme. 2014. Formal variance and semantic changes in borrowing: Integrating semasiology and onomasiology. In Eline Zenner \& Gitte Christiansen (eds.), New perspectives on lexical borrowing: Onomasiological, methodological and phraseological innovations, De Gruyter Mouton, 65-100. DOI: 10.1515/9781614514305.65 